\title{
THE ROLE OF ENVIRONMENTAL STUDIES IN MORAL EDUCATION OF JUNIOR SCHOOL STUDENTS
}

The paper presents the opportunities provided by the subject "Environmental Studies" for moral education of junior school students. The relevance of investigating this phenomenon for personality development has been discovered. It has been stated that the role of moral education of primary school students depends on the use of the following major techniques of educational impact: ethical instruction, moral behaviour encouragement. The authors focused attention on the use of environment-related material in this vector of education.

Keywords: moral education, humanism, environmental friendliness, Environmental Studies, nature, junior school students.

Introduction. In today's post-industrial world with the dominating triad "education - science - innovations", an emphasis is put on the formation of various competences in young people. As a result, they should become in-demand specialists in different branches of economy and provide the development of economic and scientific potential of the state. The $21^{\text {st }}$ century is considered to be computerised. However, the growth of scientific potential stipulates the enhanced responsibility for all what is happening on our planet; the role of collective work, joint efforts in peacemaking, improvement of environment and mankind survivability are becoming more significant. Social morality is rising to a new level. In view of this, the mechanisms of internal control and self-regulation of human behaviour (conscious ethical, humane activity) are gaining importance.

Starting school appears to be the qualitatively new stage in the development of moral consciousness: on the one hand, the ideas formed in preschool age are being developed and upgraded; one the other hand, this stage is characterised by the active acquisition of new concepts about morality, that is, moral knowledge. It is worth noting that moral knowledge forms the basis for the development of moral consciousness in junior school age and is one of its principle components. Understanding the essence of the categories of the good and the evil, the good and the bad will result in correct choice of a child's deeds that would meet the requirements of moral standards and principles. Moral beliefs that characterise human behaviour and deeds are fundamental for revealing personality's volitional qualities (courage and resolution, braveness and endurance, persistence and patience, tolerance to negative influence) and are formed at an early age. All-round influence of the society and flexible sensory affect junior schoolchildren's moral development. That is why, a great number of children's deeds are impulsive and depend on certain situations. However, moral standards acquired at preschool age become deeply realised and turn into firm moral principles at school age.

Junior preschool age is a particular stage of a child's physiological development and the period of forming conscious attitude to others or the environment, when personality's orientation (civil, community or egoistic, individualistic) is determined. Moral education was studied by Yu. Babanskyi, H. Vashchenko, B. Hrinchenko, A. Makarenko, S. Rusova, V. Sukhomlynskyi, $\mathrm{K}$. Ushynskyi, et al. The issues of instilling moral qualities in schoolchildren, their essence and conditions for their formation were investigated in research works by I. Bekh, O. Hordiichuk, N. Nychkalo, O. Savchenko, H. Tarasenko, K. Chornoita, et al. N. Vytkovska, D. Dzhola, A. Shcherbo noted that nature plays a significant role in the formation of junior schoolchildren's moral culture. Other researchers proved this statement and emphasised the importance of schoolchildren's direct interaction with nature.

The concept of culture is quite complicated. General culture of a personality consists of the following components: intellectual, legal, aesthetic, moral, and physical. Moral culture plays a special part in junior schoolchildren's personal qualities. It demonstrates personality's attitude to other individuals, team, society, and nature. Morality is significantly manifested in children's activities in natural environment. Nature can be influential for forming the basics of junior schoolchildren's morality.

The aim of the paper is to demonstrate the opportunities of the subject "Environmental Studies" in the formation of junior schoolchildren's morality.

Research methods: review of scientific and pedagogical literature, content analysis of the subject Environmental Studies, elementary theoretical synthesis, deduction.

Discussion. V. Sukhomlynskyi wrote, "The world of a child is first of all nature that surrounds him/her in childhood, parents' care, a fairytale, a song. Memories of 
this world remain for the rest of his/her life, add emotional colouring to all aspirations, thoughts, impulses. Coming into child's life with the first feelings, perceptions, imaginations, nature becomes obvious criterion of values, source of abundance. This fact provides vast opportunities for the development of a harmonious, wellround person" [4, p. 536-537]. His work demonstrated that the opportunities of Environmental Studies are much more greater than simple acquisition of certain knowledge about nature, arranging excursions and teaching children how to behave in nature. The programme of Environmental Studies involves learning a number of related concepts, the formation of junior schoolchildren's competence in environmental issues. Its spirally concentric structure implies that these concepts are to be learned more and more thoroughly each year.

At the same time, the tasks of teaching this subject are "acquisition of ethical attitude to nature and instilling love of nature of one's native country" [3].

We believe that the work directed at schoolchildren's moral education with the help of nature can be represented as successive solution to the following tasks: expanding, deepening and systematisation of children's knowledge about moral standards and rules of cultural behaviour in natural environment; arouse schoolchildren's desire to behave in a civilised manner, comply with the rules for schoolchildren as well as other moral and ethical norms; to develop negative and hostile attitude to dehumanised phenomena in natural environment.

Morality is based on humanism. In contemporary anthropogenic society, humanistic behaviour depends on the quality of value orientations at relationships with nature. H. Tarasenko in her research works focused teachers' attention on the fact that "when working with students, a teacher should bear in mind that knowledge about nature does not always determine children's attitude to it; so, an educator should be ready not only to transmit certain knowledge about nature, but to affect schoolchildren's emotional and volitional sphere" [5, p. 4].To encourage and develop humanistic attitude to nature means to declare morality. Humanistic attitude to everything alive educates general moral qualities of a personality. Nowadays we can observe that human activity has done severe damage to nature, which has led to harmful influence on people. That is why, it is important to develop a firm attitude: to make environment condition better, not worse. It is a kind of demonstration of care for a man and mankind as a whole. A colourful expression characterising such an attitude may be the following: "To save nature means to save oneself as a part of it".

Thus, at Environmental Studies classes the teacher is supposed to make ethical truths about humanism as a core and criterion of cultural attitude to nature a part of feelings, thoughts and activities of a child.

The subject "Environmental Studies" has extensive resources for moral education by means of nature. When learning first topics of Environmental Studies ("The World Around", for example), students consolidate their knowledge about nature and environment, objects of animate and inanimate nature, natural and artificial objects. Schoolchildren start to understand what conditions are necessary for human life and general importance of nature and, as a result, give examples of caring attitude to nature. The content of textbooks for primary schools makes it possible for schoolchildren to get acquainted with conditions necessary for living, devices for nature cognition, rules of behaviour in nature.

Tutorial apparatus of the textbooks contains various questions aimed at actualising basic knowledge and its consolidation, observation tasks ("How does a seed sprout?", "Watch how the position of the Sun changes on the horizon during the day" [2], etc.), exploration tasks ("Find out what temperature is the most appropriate for sunflower seeds' sprouting?", "Prove that chalkstone dissolves in water", "How to desalt water?" [2, p. 5], etc.), practical activities ("Mark the parts of the world's water on the contoured map: the Pacific, the Atlantic, the Indian, the Arctic", "Studying the collection of mineral resources", "Houseplants propagation" [2], etc.), sections "Use your intelligence", "Check yourself".

At the same time, these activities of schoolchildren demonstrate practical significance of nature for a man, which is not enough for humanistic education. Firstly, unscrupulous attitude to nature can be also justified by benefit, albeit temporary. Humanistic attitude should be based on the idea of care for not only oneself, but for others at the present time and in future. For example, a Ukrainian poet Mykola Synhaivskyi has a poem that depicts a description of a spring. Studying its meaning facilitates the formation of schoolchildren's social activism in saving water resources, development of their humane attitude to the diversity of nature in all of its elements. At this stage it is reasonable to lead a discussion on the topic "Be healthy as water" and demonstrate the importance of water for all life forms, which was the reason for our ancestors' respect for it. In addition, the teacher can use some ethnographic material on the subject: proverbs, sayings, national traditions. For instance, national epic presents the idea of living and dead water: clean water was considered to be living and curative; the image of dead water is the one from a polluted water pond that is common for today's environment. The pictures and graphics offered by textbooks stimulate contemplation and making certain decisions. For example, the textbook for year one pupils offers such a task: "Look at the pictures of the cities. Use a small circle to cover the one you would like to live in". It is important that in this case the children are motivated to explain their choice [1, p. 37].

Secondly, human relationships with nature go beyond gaining benefit. So Environmental Studies as an academic subject is designed to educate aesthetic and humanistic views of junior schoolchildren. Environmental friendliness cannot result from practical use of environmental resources, but is based on person's love of nature. In this regard, the textbooks propose thought-provoking 
tasks, for example, "Look at the picture and tell how nature teaches us to be kind" [1, p. 27].

As long as love of nature is the determining factor of the formation of humanistic attitude to it, it is important for junior schoolchildren to understand the importance of nature for people, admire it, realise that it is a part of their native country, feel its beauty and greatness. Exploring nature a person acquires certain knowledge and experience that are manifested in new discoveries and developments. In order to demonstrate the relations between studies and real life, it is reasonable to supplement instructional material with certain examples.

The schoolchildren may be motivated for nature protection by the example of their peers. The following tasks are designed with this purpose: "Look at the pictures. Which child is concerned about nature and who is doing harm to it?", "How do you take care of nature?", "Plant a tree together with adults in spring. Make a bird feeder for winter" [1, p. 28, 29].

Art (music, pictures and literary works) can assist teachers in educating morality by means of nature. For instance, when learning plant species, the schematic and descriptive text about biological properties of a plant can be supplemented by a literary text about the same plant.

The role of teacher's work, namely teacher's ability to see nature, feel it or tell about it in an artistic manner, is significant for educating nature friendliness. Such an attitude is observed during lessons-nature tours. These tours play an important role in the process of schoolchildren's cognition of nature. Actions facilitate the formation of cognitive capabilities; the skills of conscious and caring attitude to nature are acquired. According to the topic of the lesson, the teacher arranges the itinerary and chooses the subject for exploration. It is important to choose such an area where the pupils will be able to explore natural objects and to be engaged in environmental protection activities: hanging up bird feeders, collecting the seeds of rare plants, etc. The new edition of Environmental Studies programme involves excursions to the eco-naturalistic centre, animal clinic, animal shelter; if possible, to the spring, river, lake, pond, nature reserve, wildlife reserve, botanic garden, etc. Lessons outdoors facilitate acquisition of knowledge about nature and corresponding development of a child.

Particular attention of primary school children should be paid to studying the topic "The Red Book of Ukraine". Except for the information about the Book and colour of pages with rare plants and animals (declining species of plants and animals are placed on red pages, vulnerable species - on the yellow ones, rare species - on the white ones, insufficiently studied - on the red ones and finally, the species restored by human efforts on green pages), the programme involves preparing a project "The Red Book of Ukraine" by the children (year two). The results of schoolchildren's exploration work are presented in the form of a multimedia presentation, portfolio, folder, album, etc. It is up to schoolchildren to choose the form of their presentation. However, the teacher can prompt them to make a certain decision. It is important for children to conclude that the species listed in the Red Book cannot survive without people's help.

Project work stimulates education of junior schoolchildren's moral qualities related to exploring and protecting nature. It facilitates the formation of the skills of emotional and volitional sphere, communication in the society; the ability to be sensitive to other people's needs, accept other's judgments. As an educational assignment, a project is designed to solve the problems associated with creating the learning output represented in one of presentation forms. The programme involves preparing the following projects: "Let us save the spruce's life", "How to economise water in everyday life?", "Which of the nature's gifts is the most valuable for mankind (air, water, animals, plants, soil, mineral resources)?", "Act of kindness to nature". Exploratory and research practices of working on the above mentioned projects contribute to the development of critical thinking in terms of evaluation of environmental objects and phenomena as well as understanding the necessity for caring attitude to them. Such an activity becomes "an indicator" of schoolchildren's intellectual and moral development.

Empirical studies conducted among year four pupils demonstrated that in case teaching methods and techniques have been chosen properly, the content of the subject "Environmental Studies" contributes to the formation of moral qualities in primary school children. Performing the tasks (tests), the pupils were supposed to apply observation method. The test presented three reallife situations of children's behaviour in natural environment. The schoolchildren were supposed to imagine themselves in each situation and decide how they would behave according to their emotions and feelings. The variants demonstrated primary school children's concerned or indifferent emotional attitude to nature of their native country.

After applying the technique aimed at evaluating schoolchildren's emotional attitude (situational test), it was possible to distinguish three types of emotions demonstrating different behaviour in natural environment: 1) caring; 2) situational; 3) indifferent.

Schoolchildren's caring attitude to nature of their native country is demonstrated by their concern about its condition and preservation. We have found that most schoolchildren $(76.68 \%)$ give precedence to environmental friendliness; they believe that a man is a part of nature and dependent on it, so people must save it. Variable attitude to nature demonstrates personality's uncertainty about his/her emotions in a certain situation. Some schoolchildren marked two or even three answers at the same time when they had to choose positive, neutral or negative attitude. However, the number of such children was insignificant $(15.73 \%)$. Some of the schoolchildren showed indifferent attitude to nature $(7.6 \%)$.

Analysis of the research results has shown the importance of nature as a means of junior schoolchildren's moral education. 
Conclusions. In the process of mastering the subject "Environmental Studies", junior schoolchildren's moral attitudes are formed. The latter affect the children's future interests. The carried out research does not cover all the

\section{ЛІТЕРАТУРА}

1. Гільберг Т. Г. Природознавство. Підр. для 1 класу / Т. Г. Гільберг, Т. В. Сак. - К. : «Генеза», 2012. - 112 с.

2. Гільберг Т. В. Природознавство. Підр. для 3 класу / Т. Г. Гільберг, Т. В. Сак. - К. : «Генеза», 2013. - 176 с.

3. Навчальні програми для початкової школи [Електронний ресурс]. - 2016. - Режим доступу : http://osvita.ua/school/program/8793/

\section{REFERENCES}

1. Hilberh, T. H., \& Sak, T. V. (2012). Pryrodoznavstvo. Pidruchnyk dlia 1 klasu [Environmental studies. Textbook for 1st year pupils]. Kyiv: «Heneza» [in Ukrainian].

2. Hilberh, T. H., \& Sak, T. V. (2013). Pryrodoznavstvo. Pidruchnyk dlia 3 klasu [Environmental studies. Textbook for 3rd year pupils]. Kyiv: «Heneza» [in Ukrainian].

3. Navchalni prohramy dlia pochatkovoi shkoly [Academic programmes for primary school]. (2016). Retrieved from: http://osvita.ua/school/program/8793/ [in Ukrainian]. aspects of moral education with the help of nature. The issues of moral education in the organisation of extracurricular work related to Environmental Studies at primary school should be investigated further.

4. Сухомлинський В. О. Вибрані твори в 5 т. / В. О. Сухомлинський. - Т.5. - К. : Рад. школа, 1976. $639 \mathrm{c}$.

5. Тарасенко Г. С. Паросток. Методика гуманістичного виховання молодших школярів засобами природи. $1-4$ класи. Посібник для вчителя / Г. С. Тарасенко. Тернопіль : Навчальна книга, 2003. - 144 с.

4. Sukhomlynskyi, V. O. (1976). Vybrani tvory [Selected works]. (Vols. 5). Kyiv: Radianska shkola [in Ukrainian].

5. Tarasenko, H. S. (2003). Parostok. Metodyka humanistychnoho vykhovannia molodshykh shkoliariv zasobamy pryrody. 1 - 4 klasy. Posibnyk dlia vchytelia [A sprout. Methods of humanistic education of primary school children with the help of nature. Year 1-4. Teacher's book]. Ternopil: Navchalna knyha [in Ukrainian].

\section{Маріанна Василівна Горват, кандидат педагогічних наук, старший викладач, Марія Іванівна Кузьма-Качур, кандидат педагогічних наук, дочент, кафедра теорії та методики початкової освіти, Мукачівський державний університет, вул. Ужсгородська, 26, м. Мукачево, Украӥна}

\section{МІСЦЕ ПРЕДМЕТА «ПРИРОДОЗНАВСТВО»У МОРАЛЬНОМУ ВИХОВАННІ МОЛОДШИХ ШКОЛЯРІВ}

У статті розглянуто можливості предмету «Природознавство» у моральному вихованні учнів початкової школи. Проаналізовано останні дослідження 3 проблеми та зроблено висновок про те, що науковці доводять неабияку значущість природи в моральному вихованні, високо оцінюють роль безпосереднього контакту учнів із природою. Автори стверджують, що роботу з морального виховання молодших школярів засобами природи можна представити як послідовне розв'язання таких завдань: розширювати, поглиблювати і систематизувати знання дітей про моральні норми і правила культурної поведінки в природі; викликати у школярів активне бажання культурно поводитися, додержуватись правил для учнів та інших морально-етичних норм, виробляти негативне, неприязне ставлення до антигуманних виявів у навколишньому природному середовищі. У своїх дослідженнях автори доводять, що моральність базується на гуманізмі. Таким чином, одним із завдань вчителя на уроках природознавства є досягнення того, щоб етичні істини про гуманізм як внутрішній стержень та критерії культурного ставлення до природи й людини увійшли і в почуття, і в мислення, і в діяльність дитини. Предмет «Природознавство» приховує в собі величезні резерви морального виховання засобами природи. Емпіричні дослідження, проведені авторами серед учнів четвертого класу, показали, що зміст предмету «Природознавство» при ефективному підборі методів і прийомів навчання сприяє формуванню моральних якостей молодших школярів. У результаті застосування методики оцінювання емоційного ставлення учнів (ситуативний тест) виділялись три види емоцій, що відображали різну поведінку у природі: 1) турботливу; 2) ситуативну; 3 ) байдужу. Нами виявлено, що більшість учнів (76,68\%) надають перевагу турботливому ставленню до природи; вважають, що людина є частинкою природи, залежна від неї, тому повинна її берегти. Аналіз результатів дослідження показав ефективність природи як засобу морального виховання молодших школярів. Таким чином, у процесі оволодіння молодшими школярами знаннями з предмету «Природознавство» у них формуються моральні установки, які впливають на їхні подальші захоплення.

Ключові слова: моральне виховання, гуманізм, бережливе ставлення до природи, Природознавство», природа, молодші школярі. 
Марианна Васильевна Горват, кандидат педагогических наук, стариий преподаватель, Мария Ивановна Кузвма-Качур, кандидат педагогических наук, дочент, кафедра теории и методики начального образования, Мукачевский государственный университет, ул. Ужгородская, 26, г. Мукачево, Украина

\section{МЕСТО ПРЕДМЕТА «ПРИРОДОВЕДЕНИЕ» В МОРАЛЬНОМ ВОСПИТАНИИ МЛАДШИХ ШКОЛЬНИКОВ}

В статье рассмотрены возможности предмета «Природоведение» в нравственном воспитании учащихся начальной школы. Проанализированы последние исследования по проблеме и сделан вывод о том, что ученые подтверждают значимость природы в нравственном воспитании, высоко оценивают роль непосредственного контакта учащихся с природой. Авторы утверждают, что работу по нравственному воспитанию младших школьников средствами природы можно представить как последовательное решение следующих задач: расширить, углубить и систематизировать знания детей о моральных нормах и правилах культурного поведения в природе; вызвать у школьников активное желание культурно себя вести, соблюдать правила для учащихся и другие морально-этические нормы; научить проявлять негативное, неприязненное отношение к антигуманным проявлениям в окружающей среде. Авторы доказывают, что нравственность основана на гуманизме, поэтому, одной из задач учителя на уроках является достижение того, чтобы этические истины о гуманизме как внутренний стержень и критерии культурного отношения к природе и человеку вошли и в чувства, и в мышление, и в деятельность ребенка. Предмет «Природоведение» скрывает в себе огромные резервы нравственного воспитания средствами природы. Эмпирические исследования, проведенные авторами среди детей, обучающихся в четвертом классе, показали, что содержание предмета «Природоведение» при эффективном подборе методов и приемов обучения способствует формированию нравственных качеств младших школьников. В результате применения методики оценки эмоционального отношения учащихся (ситуативный тест) выделялись три вида эмоций, которые отражали различное поведение на природе: 1) заботливое; 2) ситуативное; 3) равнодушное. Нами выявлено, что большинство учащихся $(76,68 \%)$ отдают предпочтение заботливому отношению к природе, считают, что человек является частью природы, зависит от нее, поэтому должен ее беречь. Анализ результатов исследования подтвердил, что природа является эффективным средством нравственного воспитания младших школьников. Таким образом, в процессе овладения младшими школьниками знаниями по предмету «Природоведение» у них формируются нравственные установки, которые влияют на их дальнейшие увлечения.

Ключевые слова: нравственное воспитание, гуманизм, бережное отношение к природе, «Естествознание», природа, младшие школьники.

Рецензент: д. пед. н., проф. Г. В. Товканеи

Подано до редакиії 16.12.2016 